\title{
Climatology of Aerosol Optical Properties at Storm Peak Laboratory
}

\author{
Crystal M. Japngie-Green ${ }^{1}$, Elisabeth Andrews ${ }^{3,4}$, Ian B. McCubbin², John A. Ogren ${ }^{3,4}$, \\ Anna G. Hallar ${ }^{1,2 *}$ \\ ${ }^{1}$ Department Atmospheric Sciences, University of Utah, Salt Lake City, UT 84112, USA \\ ${ }^{2}$ Storm Peak Laboratory, Desert Research Institute, Steamboat Springs, CO 80477, USA \\ ${ }^{3}$ NOAA, Earth System Research Laboratory, Boulder, CO 80305, USA \\ ${ }^{4}$ Cooperative Institute for Research in Environmental Sciences, University of Colorado, Boulder, CO 80309, USA
}

\begin{abstract}
Aerosols create large uncertainty in the planetary energy balance due to both direct and indirect radiative forcing. Understanding aerosol seasonal patterns is essential for accurate climate change prediction, but mountain regions are often difficult for climate models to resolve. Therefore, long-term observations collected at high elevations are particularly useful. In-situ surface aerosol optical measurements were analyzed for the years 2011-2016 at a mountain site located in western Colorado and tied to potential sources based on relationships among the aerosol properties.

The peak values for the scattering and absorption coefficients were observed during the summer, suggesting greater aerosol loading (likely due to wildfires), whereas the lowest values were observed during the winter, indicating cleaner conditions (due to less influence from the boundary layer). The scattering Ångström exponent, a property that provides information about size distributions, revealed the predominance of coarse-mode particles during the spring, which is consistent with the presence of dust. The aerosols observed during the summer, however, were mostly composed of finemode particles. This increase in the fine fraction points to combustion, likely wildfires during the dry season (Hallar, 2015), as a source, which is further supported by the absorption Ångström exponent dropping to its lowest value (close to 1) during the summer after exhibiting a slightly higher value ( 1.3) during the spring. Schmeisser et al. (2017) suggests that, for in-situ aerosol, absorption Angstrom exponents larger than 1.5 may be indicative of dust if they are associated with low $(<1.3)$ scattering Ångström exponents. The increase in combustion aerosols during the summer accompanied by high values for the single scattering albedo suggests that these aerosols underwent processing in the atmosphere before reaching Storm Peak Laboratory. These results are important for improving visibility and predicting future aerosol concentrations in the western U.S.
\end{abstract}

Keywords: Absorption; Scattering; In-situ measurements; Mountain; Climate.

\section{INTRODUCTION}

Atmospheric aerosols change rapidly over short time intervals, making future concentrations difficult to predict (Laj et al., 2009). Establishing aerosol climatology is important for identifying aerosol sources, distributions, and transport (Yu et al., 2009; Hand et al., 2017). By revealing seasonal aerosol patterns of a region, improvements can be made to climate models (Chung et al., 2005) and visibility by identifying aerosol sources (Hirdman et al., 2010). There is large disagreement among climate models related to aerosol spatial distributions and the direct and indirect

\footnotetext{
${ }^{*}$ Corresponding author.

Tel.: 801-581-6136; Fax: 801-585-3681

E-mail address: gannet.hallar@utah.edu
}

radiative forcing effects of these aerosols (Reddington et al., 2017).

Aerosols absorb and scatter radiation and thus have a direct effect on the planetary energy balance. These effects can be quantified by calculating direct radiative forcing from measured aerosol optical properties. Direct aerosol radiative forcing is dependent upon particle composition, size, and concentration (Haywood and Boucher, 2000). The current estimate from the Intergovernmental Panel on Climate Change of direct aerosol radiative forcing is $-0.35 \pm 0.5 \mathrm{~W} \mathrm{~m}^{-2}$ (Stocker et al., 2013). The large uncertainty associated with this value is a consequence of rapidly changing aerosol distributions with respect to time and location (Stocker et al., 2013), model uncertainties (Reddington et al., 2017), and varied aerosol composition (Jacobson, 2001).

Aerosols also influence the radiation balance by indirect mechanisms. Due to their role as potential cloud condensation nuclei $(\mathrm{CCN})$, aerosols can change the energy balance by 
altering cloud properties. When $\mathrm{CCN}$ concentrations are high, clouds will be composed of more droplets of smaller diameter and thus have different optical properties (Twomey, 1977). Clouds composed of smaller droplets can persist longer due to delayed precipitation, resulting in further changes to the radiation balance (Albrecht, 1989).

Feedbacks that influence future aerosol climatology are another important consideration for numerical model accuracy. For example, wildfires are a common source of atmospheric aerosols during the summer months and are expected to increase as the climate warms (Spracklen et al., 2009). Increased aerosol loading leads to diminished incoming solar radiation at the surface due to light extinction (Charlson et al., 1992). Decreased solar radiation has been linked to milder summer monsoons in the southwestern U.S. (Diffenbaugh et al., 2006). A strong correlation between drought and wildfire has also been observed (Westerling et al., 2006), ultimately creating a positive feedback for aerosol loading and additional cooling of the climate system. Using numerical models, Spracklen et al. (2009) projected a $40 \%$ increase in organic carbon due to increased wildfire activity by the year 2050. Hallar et al. (2017) estimated this value to be lower, at $24 \%$ for the Colorado Rockies and 36\% for the Wasatch and Uintah Mountains, an important consideration for numerical climate models since aerosols moderate warming. The net effect of these mechanisms is unclear due to competing feedbacks that are not well understood or quantified.

Previous studies and climate models relied heavily on aerosol optical depth (AOD) in order to observe aerosol loading and transport. AOD is an integrated measurement of aerosols throughout the entire atmospheric column that is measured using satellite or ground-based radiometers. Remote sensing measurements are particularly valuable because they can gather aerosol data over large horizontal areas and represent total vertical aerosol concentration (Chung et al., 2005; Wang et al., 2012). While useful, these measurements lack information regarding the vertical distribution of aerosols within the column. The vertical distribution has an effect on radiative forcing (Sanroma et al., 2010) and can also provide information about aerosol transport and sources. For example, greater AODs have been observed during the spring with the transport of Asian dust to North America by extratropical cyclones (Yu et al., 2008). Hallar et al. (2015) observed that, at their mountain site in Colorado, in-situ measurements made at the surface did not spike in the spring with AOD measurements, suggesting the aerosols contributing to the seasonal increase in AOD were located above the surface.

Surface in-situ measurements can provide additional aerosol information using different methodologies than those used to find AOD. Unlike remote sensing measurements, for in-situ measurements the air is sampled within instruments to obtain the aerosol absorption and scattering coefficients. This approach allows continuous data to be obtained at the surface at a specific location regardless of atmospheric conditions (e.g., clouds or nighttime). For some aerosol properties, such as absorption and single scattering albedo, remote sensing techniques can have high uncertainty, emphasizing the importance of in-situ measurements (Dubovik, 2000). Combining remote sensing with in-situ measurements provides more comprehensive information for improving direct radiative forcing estimates (Andrews et al., 2004; Yu et al., 2009).

While global values of radiative forcing have large uncertainty, regional estimates are even more variable (Yu et al., 2009). Gathering long-term in-situ data from various sites is one way to reduce this uncertainty (Andrews et al., 2011; Pandolfi et al., 2018). Mountain regions create unique difficulties for climate models due to complex terrain and insufficient model resolution (Giorgi, 2005). Therefore, data collected at high elevations will be especially valuable for improving climate models, particularly as the spatial resolution of the models improves.

In the following sections, in-situ aerosol optical property data collected from 2011 to 2016 at a high elevation site in the western U.S. are analyzed to identify seasonal aerosol trends. Scattering and absorption coefficients are used to calculate a variety of aerosol optical properties that can help to establish the aerosol climatology of the region and illuminate the possible sources of these aerosols.

\section{METHODOLOGY}

\section{Location}

Storm Peak Laboratory (SPL) is a mountain-top site $(3220 \mathrm{~m})$ located in western Colorado $\left(40.455^{\circ} \mathrm{N}, 106.745^{\circ}\right)$. Due to its remote location, SPL has little influence from traffic or industry of nearby cities (Hallar et al., 2016) and has been used for aerosol research since the 1990s. All data for this project was collected at SPL and went through a quality assurance process to remove spikes due to local contamination (e.g., ski area vehicles) as well as periods when the instruments were not working or being maintained. The edited data was submitted to the EBAS Level 2 data archive (http://ebas.nilu.no). Measurements were taken in 1-minute intervals, but Level 2 data were reported as hourly averages. The Level 2 data were also reported at standard temperature $(273.15 \mathrm{~K})$ and pressure $(1013.25 \mathrm{hPa})$, and the appropriate instrument corrections were applied as described below.

\section{Instrumentation}

The scattering data were collected using a TSI 3563 nephelometer that measures the scattering coefficient, $\sigma_{\mathrm{sp}}$, at 3 wavelengths $(\lambda ; 450 \mathrm{~nm}, 550 \mathrm{~nm}$, and $700 \mathrm{~nm})$. The nephelometer data were corrected for instrument angular truncation and light source non-idealities (Anderson and Ogren, 1998). A particle soot absorption photometer (PSAP) was used to measure the absorption coefficient, $\sigma_{a p}$, at slightly different visible wavelengths $(467 \mathrm{~nm}, 530 \mathrm{~nm}$, and $660 \mathrm{~nm}$ ). Data from the PSAP was replaced in 2013 by data from a similar instrument known as a continuous light absorption photometer (CLAP; wavelengths: $467 \mathrm{~nm}$, $528 \mathrm{~nm}$, and $652 \mathrm{~nm}$ ). This instrument measures absorption in the same manner as the PSAP but contains 8 filter spots (compared to 1 filter spot for the PSAP) through which it rotates before filter replacement is required (Ogren et al., 
2017). This is advantageous because SPL is a remote site with infrequent technician visits. PSAP and CLAP data were corrected using the schemes in Bond et al. (1999) to account for scattering artifacts, spot size, and flow, and Ogren (2010) to extend the Bond corrections for all three wavelengths. Data where the filter transmittance was less than 0.5 were automatically marked as invalid during the quality control process because of limitations of the Bond correction.

A switched impactor system separated aerosols into particulate matter less than $10 \mu \mathrm{m}\left(\mathrm{PM}_{10}\right)$ and less than $1 \mu \mathrm{m}\left(\mathrm{PM}_{1}\right)$ in diameter before measurements were made by the nephelometer and PSAP/CLAP. For measurements of this type, the sample air is often dried to achieve a relative humidity of $40 \%$ or less to avoid the confounding effects of water on aerosol properties. Because SPL is located in an arid region and the measurements were made within a heated building, relative humidity values above $40 \%$ were rare (Hallar et al., 2015), eliminating the need for this step.

\section{Calculations}

The measured scattering and absorption coefficients offer information about aerosol loading at the surface. These values can also be used to calculate various intensive aerosol optical properties (intensive properties are independent of the amount of aerosol loading). The scattering Ångström exponent and absorption Ångström exponent can be calculated using measurements made at two wavelengths: $\alpha_{\mathrm{x}}=-\log \left(\sigma_{\mathrm{xp}}\left(\lambda_{1}\right) / \sigma_{\mathrm{xp}}\left(\lambda_{2}\right) / \log \left(\lambda_{1} / \lambda_{2}\right)\right)$, where $\sigma_{\mathrm{xp}}\left(\lambda_{\mathrm{i}}\right)$ is the scattering (s) (or absorption (a)) at wavelength i. The scattering Ångström exponent $\left(\alpha_{s}\right)$ can be used as an indicator of particle size, with low values corresponding to particles with greater diameter and higher values indicating smaller particles. Clarke and Kapustin (2010) experimentally obtained a threshold $\left(\alpha_{\mathrm{s}}=1.3\right)$ for the scattering Ångström exponent $(450 \mathrm{~nm} / 700 \mathrm{~nm})$ that differentiates between fine-mode aerosols $\left(\alpha_{\mathrm{s}}>1.3\right)$ and coarse-mode aerosols $\left(\alpha_{\mathrm{s}}<1.3\right)$. The absorption Ångström exponent $\left(\alpha_{\mathrm{a}}\right)$ can provide information about the composition of aerosols (e.g., Bergstrom et al., 2002, 2007). Black carbon has a theoretical value of $\alpha_{a}=1$, while dust aerosol $\alpha_{\mathrm{a}}$ tends to be larger than 2, and there is no clear consensus on typical values for biomass burning (Table 1 in Schmeisser et al., 2017, and references therein). The single-scattering albedo (SSA) is the ratio of the scattering coefficient to the extinction coefficient (the sum of absorption and scattering). SSA is high (close to 1) for aerosols that readily scatter light and lower for aerosols that strongly absorb light (black carbon has SSA $\approx 0.3$ ), providing additional information about aerosol type.

\section{RESULTS AND DISCUSSION}

Fig. 1(a) shows the monthly means of scattering coefficients for $\mathrm{PM}_{1}$ and $\mathrm{PM}_{10}$ at each wavelength $(450 \mathrm{~nm}$, $550 \mathrm{~nm}$, and $700 \mathrm{~nm}$ ). In all cases, the highest values are found during the summer months, with the peak in August. The lowest values occur during the winter months, when air is cleaner due to SPL being less influenced by the atmospheric boundary layer, which is generally the case for mountain sites (Raatikainen et al., 2014). The rate of change from spring to summer is more gradual than from summer to fall. It is probable that the spike in aerosol scattering during the summer is due to biomass burning during peak wildfire season (Hallar et al., 2015).

Monthly averages for absorption coefficients are shown in Fig. 1(b). The PSAP or CLAP absorption data were adjusted to $450 \mathrm{~nm}, 550 \mathrm{~nm}$, and $700 \mathrm{~nm}$ using the absorption Ångström exponent. This was done to accommodate calculation of SSA, which requires both absorption and scattering coefficients at the same wavelength. The absorption data follows a similar pattern to the scattering data, with the highest monthly values found during the summer season and lowest values during the winter months. As with scattering, the slope of the curve from spring to summer is not as steep as the slope from summer to fall.

While aerosol loading is an important factor for radiative forcing, information about the aerosol size distribution and composition can aid in attributing aerosol forcing to different sources. For example, natural particles such as dust tend to dominate the coarse mode (diameter $>1 \mu \mathrm{m}$ ), while anthropogenic and combustion aerosol are more dominant in the fine mode (diameter $<1 \mu \mathrm{m}$ ). When calculating the scattering Ångström exponent, an additional constraint on the scattering data was applied. Similar to Andrews et al. (2011), scattering values less than $0.5 \mathrm{Mm}^{-1}$ were omitted when calculating the scattering Ångström exponent with the purpose of minimizing noise that can occur when taking the ratio of two small numbers. This method eliminated $7.45 \%$ of the scattering data for $\mathrm{PM}_{1}$ and $6.69 \%$ of the data for $\mathrm{PM}_{10}$. Fig. 2(a) shows the monthly averaged scattering Ångström exponent for $\mathrm{PM}_{1}$ and $\mathrm{PM}_{10}$. The scattering Ångström exponent is lowest during the spring months, particularly in March when the mean value drops to 1.3 , indicating the presence of large particles at the surface; these particles are likely dust (Hallar et al., 2015), although whether they are from regional sources or due to long-range transport is unclear. During the summer months, the scattering Angström exponent is at its highest $\left(\sim 2\right.$ for $\left.\mathrm{PM}_{10}\right)$, corresponding to a greater contribution from small particles. This is likely due to increased combustion aerosols during peak wildfire activity (Hallar et al., 2015).

The monthly averaged absorption Ångström exponent is presented in Fig. 2(b). The $\alpha_{a}$ at SPL exhibits less seasonal variation than other aerosol optical properties, ranging only between 1 and 1.3 throughout the year. The lowest $\alpha_{a}$ (near 1) occurred during the summer months. The highest values for $\alpha_{\mathrm{a}}$ occurred during spring season. Some winter months also exhibit higher values for $\alpha_{a}$; however, SPL is an extremely remote site, with the cleanest conditions occurring during the winter months, which can lead to noise in the $\alpha$ calculation. The springtime values for $\alpha_{a}$ found at SPL are lower than typically suggested for dust (e.g., Table 1 in Schmeisser et al., 2017); however, the monthly $\alpha_{a}$ values represent all data for that month, not just during dust events, which tend to be sporadic and shortlived (less than 1, to 5 days; Hallar et al., 2015). 


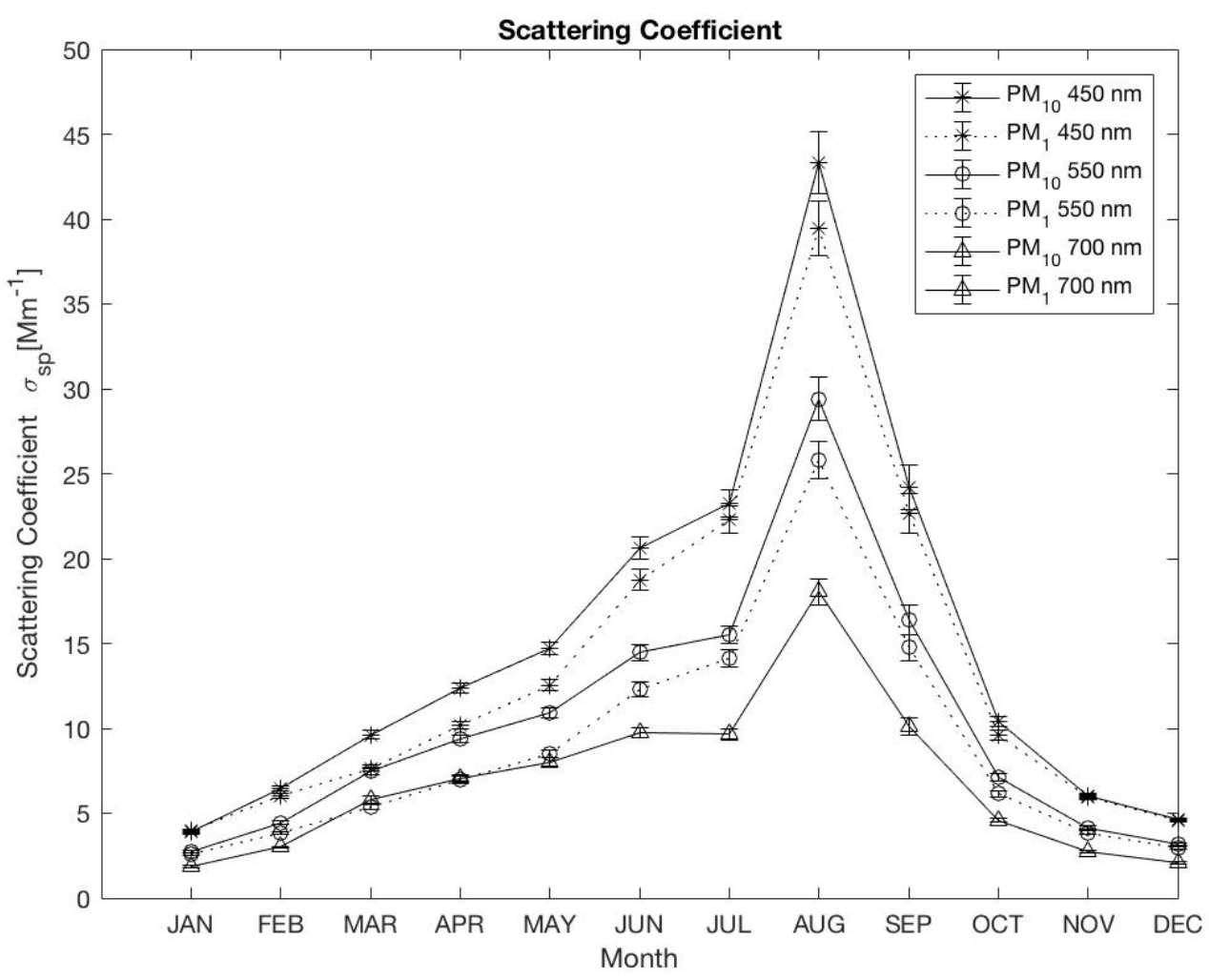

Fig. 1(a). Mean monthly scattering coefficients for years 2011-2016. Measurements at 450, 550, and $700 \mathrm{~nm}$ are represented by asterisk, open circle, and triangle markers, respectively. Solid lines are $\mathrm{PM}_{1}$, and dashed lines are $\mathrm{PM}_{10}$. The $95 \%$ confidence intervals of the monthly means are displayed using error bars.

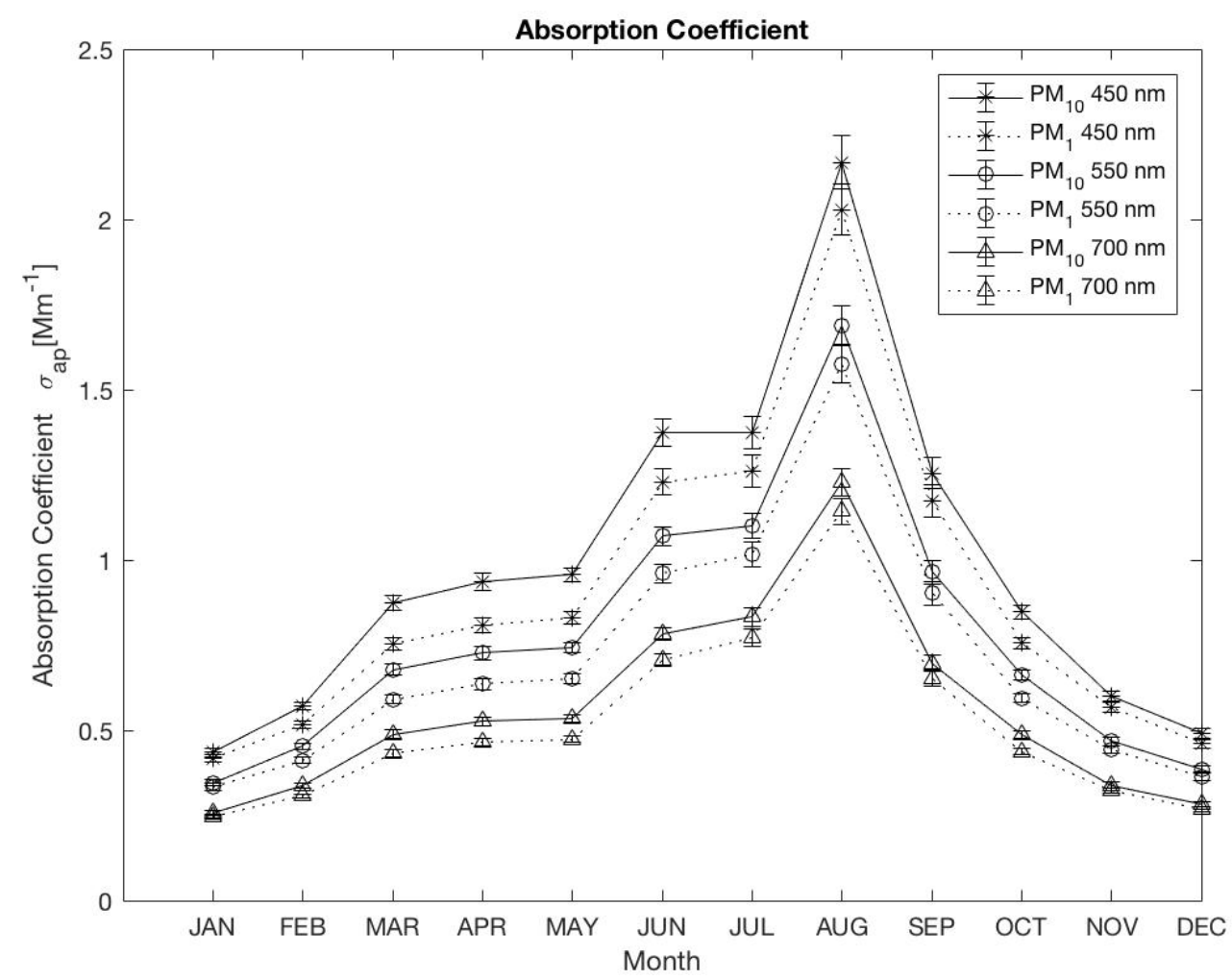

Fig. 1(b). Mean monthly absorption coefficients for years 2011-2016. Measurements at 450, 550, and $700 \mathrm{~nm}$ are represented by asterisk, open circle, and triangle markers, respectively. Solid lines are $\mathrm{PM}_{1}$, and dashed lines are $\mathrm{PM}_{10}$. The $95 \%$ confidence intervals of the monthly means are displayed using error bars. 


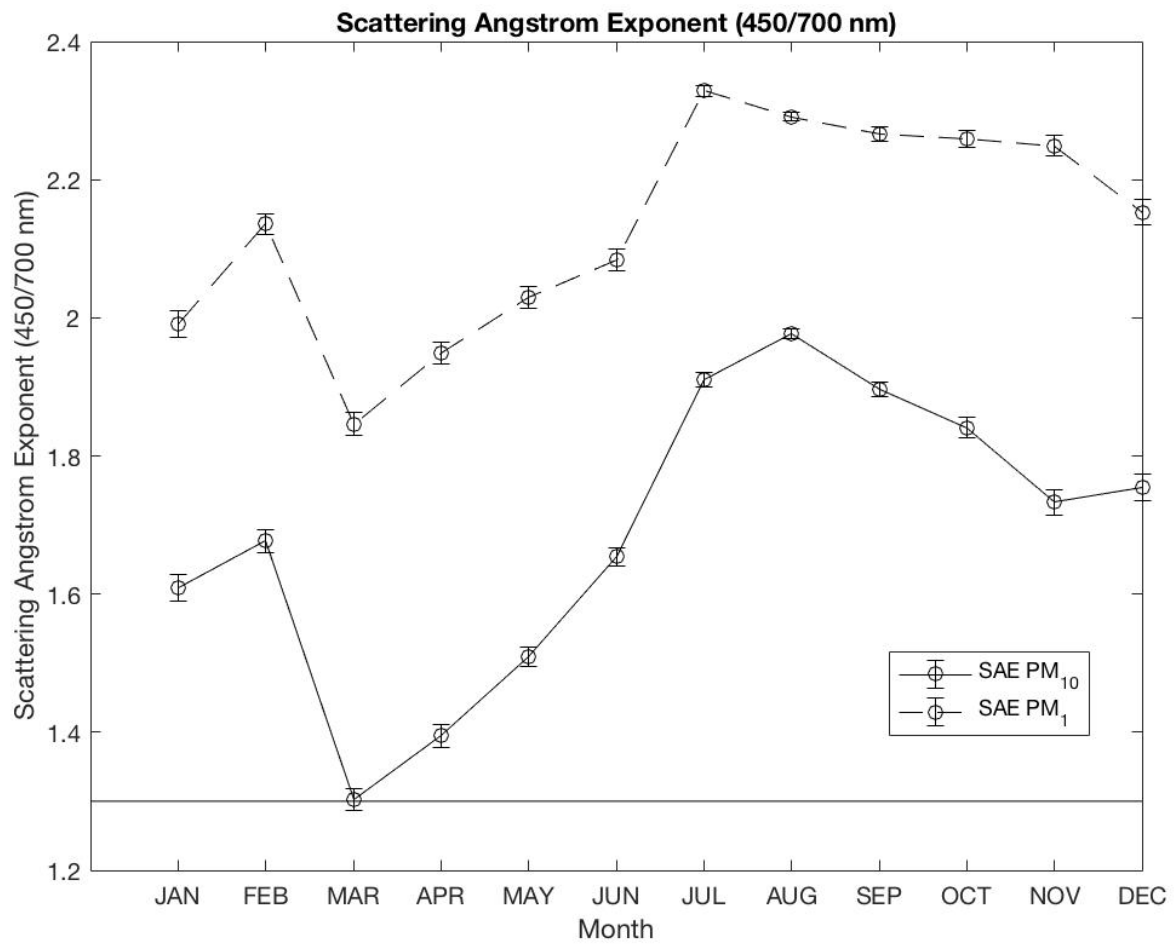

Fig. 2(a). Mean monthly scattering Ångström exponents (400/700 nm). The solid line represents $\mathrm{PM}_{10}$ and dashed line, $\mathrm{PM}_{1}$. The $95 \%$ confidence intervals of the monthly means are displayed using error bars.

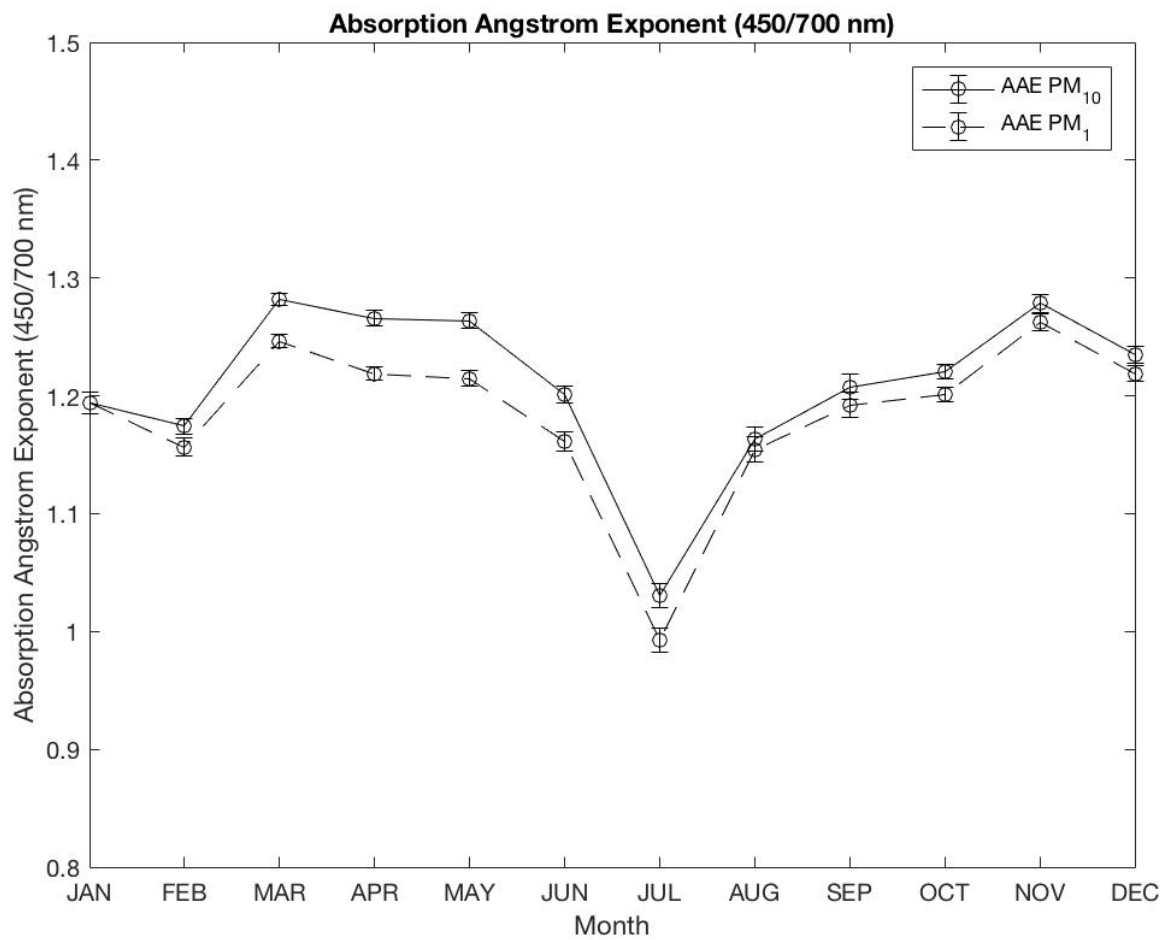

Fig. 2(b). Mean monthly absorption Ångström exponents $(400 / 700 \mathrm{~nm})$. The sold line represents $\mathrm{PM}_{10}$ and dashed line $\mathrm{PM}_{1}$. The $95 \%$ confidence intervals of the monthly means are displayed using error bars.

Fig. 3 shows a plot of the scattering Ångström exponent $(450 \mathrm{~nm} / 700 \mathrm{~nm})$ versus scattering coefficient at $550 \mathrm{~nm}$ for $\mathrm{PM}_{10}$. The scattering Ångström exponent was calculated for each hourly data point for the years 2011-2016. The black dots represent all data, green dots represent data collected during the peak dust season days (April 1-May 15) at SPL (Hallar et al., 2015), and red dots represent values from the summer season defined as days (June 19-August 13). 


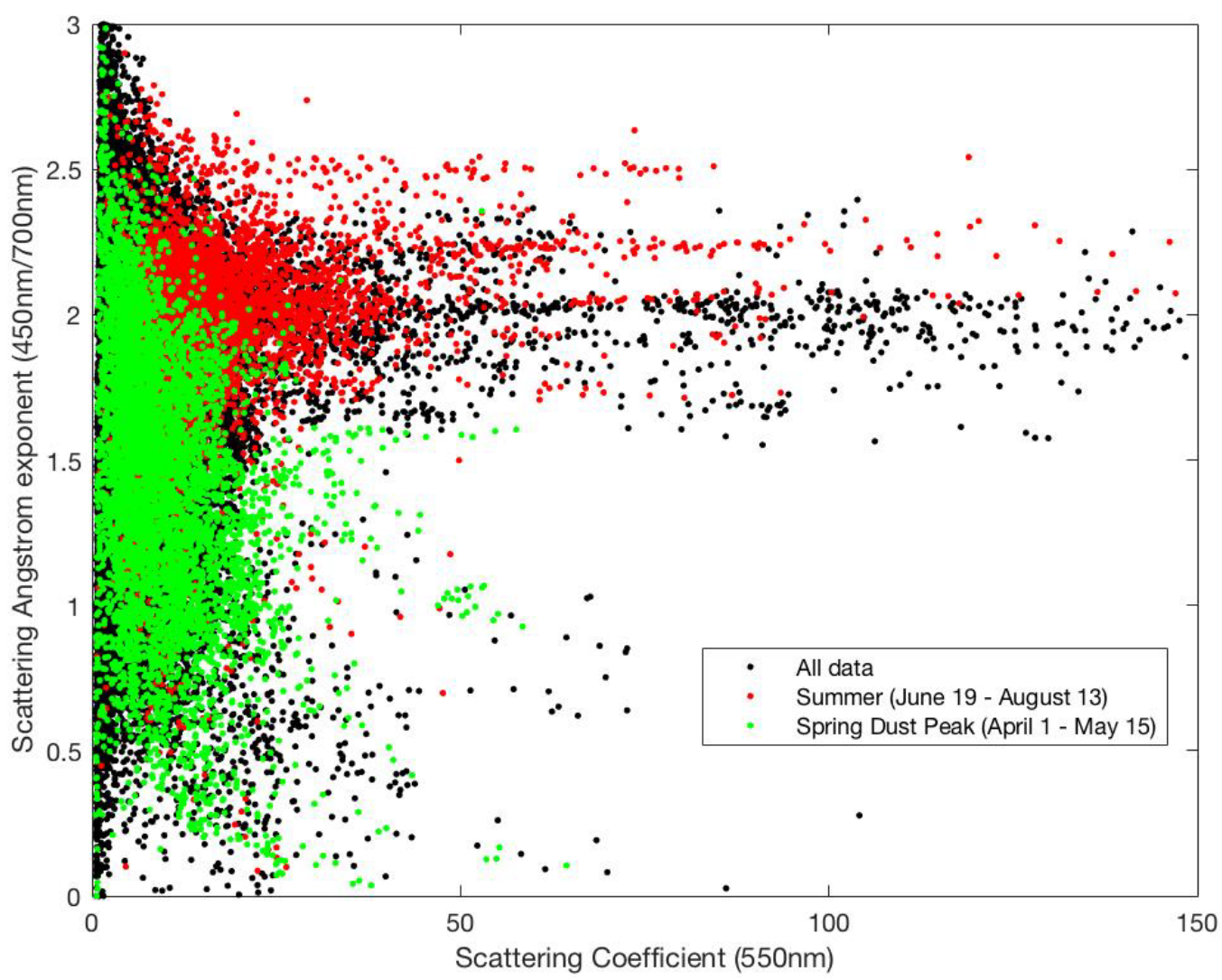

Fig. 3. Ångström exponent (450/700 nm) vs. scattering coefficient at $550 \mathrm{~nm}$ for years $2011-2016$. Black dots represent all data. Green dots occur during peak dust season (Hallar et al., 2015) from April 1-May 15 for all years. Red dots represent summer season for days June 19-August 13 of all years.

By comparing these two quantities, a relationship between aerosol loading and aerosol size with respect to season can be discerned. Fig. 3 shows two major aerosol categories. One group consists of small size particles and high aerosol loading, located in the top portion of the graph, and is associated largely with the summer months (combustion aerosols). The summer season is shown with red points in Fig. 3, and these points are primarily found with a scattering Ångström exponent greater than 1.5. Data collected during the Spring, found primarily on the lower portion of the plot, is composed of mostly coarse-mode particles (dust), as demonstrated with the lower scattering Ångström exponent. Additionally, a lower scattering coefficient was observed during the Spring season. Hallar et al. (2015) presented similar results; however, nephelometer and PSAP measurements in that study were limited to the years 2011-2013, compared to 2011-2016 for this project. In Hallar et al. (2015), aerosol optical depth values combined with surface level nephelometer data suggested that high altitude long-range transport may be primarily responsible for the strong dust signal observed at SPL in the spring. The expanded dataset presented here suggests otherwise, as there is a strong dust signal observed at the surface that is apparent from the decrease in in-situ scattering Ångström exponent during the spring.

The single scattering albedo for the $450 \mathrm{~nm}, 550 \mathrm{~nm}$, and $700 \mathrm{~nm}$ wavelengths are shown in Fig. 4. SSA was highest during the spring and summer (with the exception of June) and lowest during the winter season. We hypothesize that the seasonal variability of SSA is due to the impact of wildfires in the late spring and summer, along with an increase in emissions from home heating via wood burning during the winter months (Zhao et al., 2013).

While Fig. 3 suggests that the summer months are associated with wildfires (i.e., combustion aerosol), the SSA observed during the summer is quite high. This has previously been observed for long-range transport of smoke and is possibly associated with the condensation of gases from wildfire smoke, which can enhance the scattering of aerosol (Andrews et al., 2004).

Though dust is observed at SPL in the spring, it is difficult to identify specific dust sources without comparison to known dust events. While infrequent, Asian dust has previously been detected at SPL, though, as noted above, it was typically above the surface (Hallar et al., 2015). Hallar et al. (2015) also observed a number of dust events originating from regional (inter-mountain west) sources during the spring months. In the future, the incorporation of meteorological conditions may also yield important information regarding dust sources. Different methodologies, including aerosol chemistry, could also be utilized to identify aerosol types with higher specificity and thus help identify aerosol sources. 


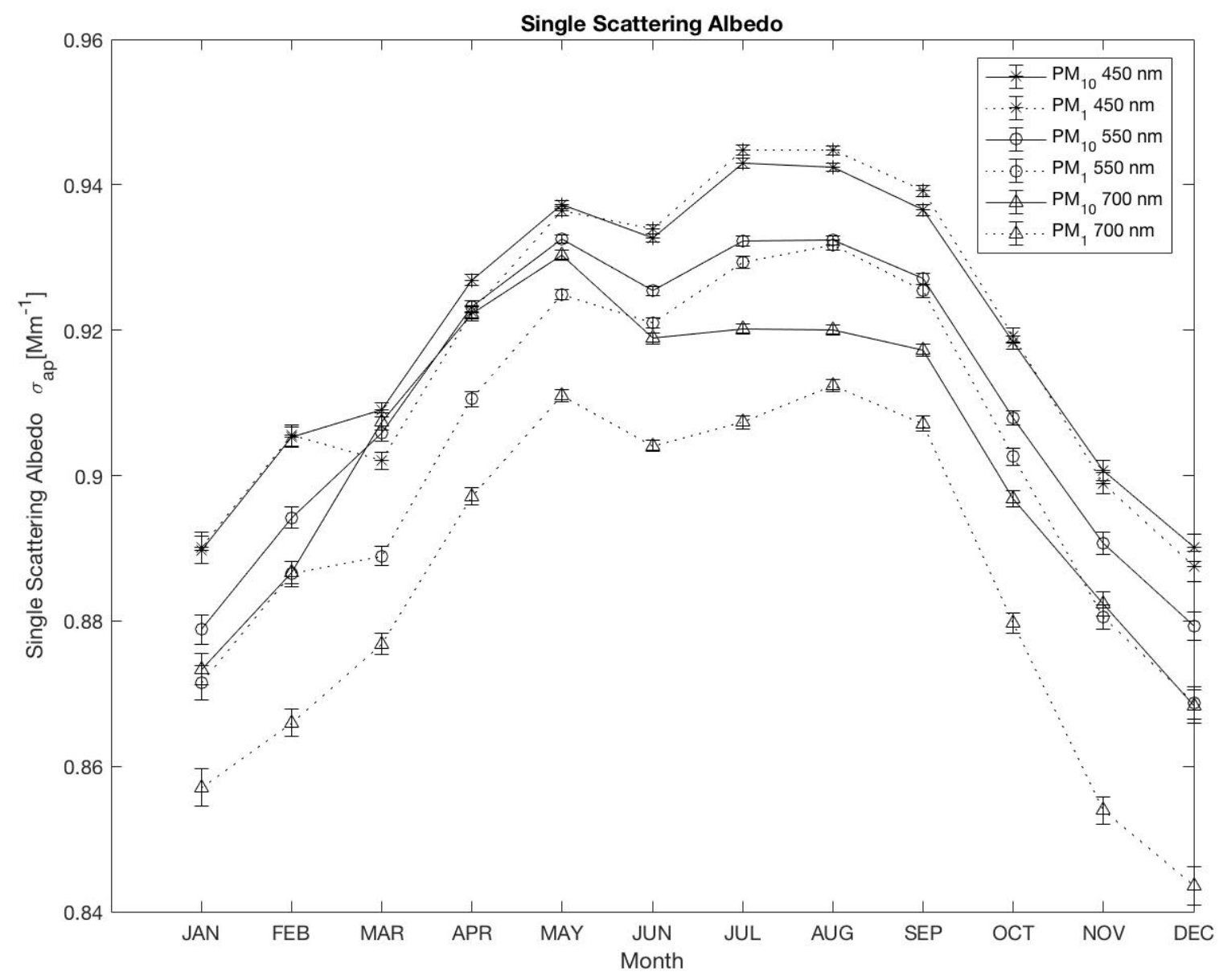

Fig. 4. Single scattering albedo at $450 \mathrm{~nm}$ (asterisk), $550 \mathrm{~nm}$ (open circle), and $700 \mathrm{~nm}$ (triangle). The solid lines represent $\mathrm{PM}_{10}$, and the dashed lines represent $\mathrm{PM}_{1}$. The 95\% confidence intervals of the monthly means are displayed using error bars.

\section{CONCLUSIONS}

The identification of aerosol seasonal patterns and sources in the western U.S. is crucial to improving visibility and climate model accuracy. In this study, the annual cycles for aerosol optical properties (the absorption, scattering, single scattering albedo, and absorption and scattering Ångström exponents) were presented and tied to known aerosol types. A strong wildfire signal was observed in the summer at SPL, yet these events were not associated with a significant decrease in SSA. These combined measurements suggest that wildfire smoke is aged and processed, reducing the direct radiative forcing impact, as the smoke is transported from the initial source.

Additionally, the aerosol climatology based on in-situ measurements at SPL presented by Hallar et al. (2015) has been updated to include the years 2013-2016. A notable new finding is the detection of a strong dust signal at the surface by in-situ measurements, whereas previous comparisons of the column and surface data suggested that most of the springtime dust remained above the surface. These results point to the impacts of regional climate change on visibility with an increasingly arid environment in the western U.S. (Hallar et al., 2017).

\section{ACKNOWLEDGEMENTS}

Ty Atkins and Joe Messina provided technical assistance with the maintenance and data quality control for the aerosol optical instruments at SPL, and we are grateful. The Steamboat Ski Resort provided logistical support and in-kind donations. The Desert Research Institute is a permittee of the Medicine Bow-Routt National Forests and is an equal opportunity service provider and employer. All data used in this analysis are available at: http://ebas.nilu.no.

\section{REFERENCES}

Albrecht, B.A. (1989). Aerosols, cloud microphysics, and fractional cloudiness. Science 245: 1227-1230.

Anderson, T.L. and Ogren, J.A. (1998). Determining aerosol radiative properties using the TSI 3563 integrating nephelometer. Aerosol Sci. Technol. 29: 57-69.

Andrews, E., Sheridan, P.J., Ogren, J.A., Ferrare, R. (2004). In situ aerosol profiles over the Southern Great Plains cloud and radiation test bed site: 1. Aerosol optical properties. J. Geophys. Res. 109: D06208, doi: 10.1029/2003JD004025.

Andrews, E., Ogren, J.A., Bonasoni, P., Marinoni, A., 
Cuevas, E., Rodríguez, S., Sun, J.Y., Jaffe, D.A., Fischer, E.V., Baltensperger, U., Weingartner, E., Collaud Coen, M., Sharma, S., Macdonald, A.M., Leaitch, W.R., Lin, N.H., Laj, P., Arsov, T., Kalapov, I., Jefferson, A. and Sheridan, P. (2011). Climatology of aerosol radiative properties in the free troposphere. Atmos. Res. 102: 365393, doi: 10.1016/j.atmosres.2011.08.017.

Bergstrom, R.W., Russell, P.B. and Hignett, P. (2002). Wavelength dependence of the absorption of black carbon particles: Predictions and results from the TARFOX experiment and implications for the aerosol single scattering albedo. J. Atmos. Sci. 59: 567-577.

Bergstrom, R.W., Pilewskie, P., Russell, P.B., Redemann, J., Bond, T.C., Quinn, P.K. and Sierau, B. (2007). Spectral absorption properties of atmospheric aerosols. Atmos. Chem. Phys. 7: 5937-5943, doi: 10.5194/acp-75937-2007.

Bond, T.C., Anderson, T.L. and Campbell, D. (1999). Calibration and intercomparison of filter-based measurements of visible light absorption by aerosols. Aerosol Sci. Technol. 30: 582-600, doi: 10.1080/027868 299304435.

Charlson, R.J., Schwartz, S.E., hales, J.M., Cess, R.D., Coakley Jr., J.A., Hansen, J.E. and Hofmann, D.J. (1992). Climate forcing by anthropogenic aerosols. Science 255: 423-430, doi: 10.1126/science. 255.5043 .423

Chung, C.E., Ramanathan, V., Kim, D. and Podgorny, I.A. (2005). Global anthropogenic aerosol direct forcing derived from satellite and ground-based observations. $J$. Geophys. Res. 110: D24207, doi: 10.1029/2005JD006356.

Clarke, A. and Kapustin, V. (2010) Hemispheric aerosol vertical profiles: Anthropogenic impacts on optical depth and cloud nuclei. Science 329: 1488-1492.

Diffenbaugh, N.S., Ashfaq, M., Shuman, B., Williams, J.W. and Bartlein, P.J. (2006). Summer aridity in the United States: response to mid-Holocene changes in insolation and sea surface temperature. Geophys. Res. Lett. 33: 22, doi: 10.1029/2006GL028012.

Dubovik, O., Smirnov, A., Holben, B.N., King, M.D., Kaufman, Y.J., Eck, T.F. and Slutsker, I. (2000). Accuracy assessments of aerosol optical properties retrieved from Aerosol Robotic Network (AERONET) Sun and sky radiance measurements. J. Geophys. Res. 105: 9791-9806, doi: 10.1029/2000JD900040.

Giorgi, F.C. (2005). Climate change prediction. Clim. Change 73: 239-265, doi: 10.1007/s10584-005-6857-4.

Hallar, A.G., Petersen, R., Andrews, E., Michalsky, J., McCubbin, I.B. and Ogren, J.A. (2015). Contributions of dust and biomass burning to aerosols at a Colorado mountain-top site. Atmos. Chem. Phys. 15: 13665-13679, doi: 10.5194/acp-15-13665-2015.

Hallar, A.G., Petersen, R., McCubbin, I.B., Lowenthal, D., Lee, S., Andrews, E. and Yu, F. (2016). Climatology of ne particle formation and corresponding precursors at Storm Peak Laboratory. Aerosol Air Qual. Res. 16: 816826, doi: 10.4209/aaqr.2015.05.0341.

Hallar, A.G., Molotch, N.P., Hand, J.L., Livneh, B., McCubbin, I.B., Petersen, R., Michalsky, J., Lowenthal, D. and Kunkel, K.E. (2017). Impacts of increasing aridity and wildfires on aerosol loading in the intermountain Western US. Environ. Res. Lett. 12: 014006, doi: 10.1088/1749-9326/aa510a.

Hand, J.L., Gill, T.E. and Schichtel, B.A. (2017). Spatial and seasonal variability in fine mineral dust and coarse aerosol mass at remote sites across the United States. $J$. Geophys. Res. 122: 3080-3097, doi: 10.1002/2016JD02 6290.

Haywood, J. and Boucher, O. (2000). Estimates of the direct and indirect radiative forcing due to tropospheric aerosols: A review. Rev. Geophys. 38: 513-543.

Hirdman, D., Sodemann, H., Eckhardt, S., Burkhart, J.F., Jefferson, A., Mefford, T., Quinn, P.K., Sharma, S., Ström, J. and Stohl, A. (2010). Source identification of short-lived air pollutants in the Arctic using statistical analysis of measurement data and particle dispersion model output. Atmos. Chem. Phys. 10: 669-693.

Jacobson, M.Z. (2001). Global direct radiative forcing due to multicomponent anthropogenic and natural aerosols. J. Geophys. Res. 106: 1551-1568. doi: 10.1029/2000JD 900514.

Laj, P., Klausen, J., Bilde, M., Plaß-Duelmer, C., Pappalardo, G., Clerbaux, C., Baltensperger, U., Hjorth, J., Simpson, D., Reimann, S., Coheur, P.F., Richter, A., De Mazière, M., Rudich, Y., McFiggans, G., Torseth, K., Wiedensohler, A., Morin, S., Schulz, M., Allan, J.D., Attié, J.L., Barnes, I., Birmili, W., Cammas, J.P., Dommen, J., Dorn, H.P., Fowler, D., Fuzzi, S., Glasius, M., Granier, C., Hermann, M., Isaksen, I.S.A., Kinne, S., Koren, I., Madonna, F., Maione, M., Massling, A., Moehler, O., Mona, L., Monks, P.S., Müller, Müller, D.T., Orphal, J., Peuch, V.H., Stratmann, F.D., Tanré, F. and Ty, G. (2009). Measuring atmospheric composition change. Atmos. Environ. 43: 5351-5414.

Ogren, J.A. (2010). Comment on "Calibration and intercomparison of filter-based measurements of visible light absorption by aerosols". Aerosol Sci. Technol. 44: 589-591, doi: 10.1080/02786826.2010.482111.

Ogren, J.A., Wendell, J., Andrews, E. and Sheridan, P.J. (2017). Continuous light absorption photometer for long-term studies. Atmos. Meas. Tech. 10: 4805-4818, doi: 10.5194/amt-10-4805-2017.

Pandolfi, M., Alados-Arboledas, L., Alastuey, A., Andrade, M., Angelov, C., Artiñano, B., Backman, J., Baltensperger, U., Bonasoni, P., Bukowiecki, N., Collaud Coen, M., Conil, S., Coz, E., Crenn, V., Dudoitis, V., Ealo, M., Eleftheriadis, K., Favez, O., Fetfatzis, P., Fiebig, M., Flentje, H., Ginot, P., Gysel, M., Henzing, B., Hoffer, A., Holubova Smejkalova, A., Kalapov, I., Kalivitis, N., Kouvarakis, G., Kristensson, A., Kulmala, M., Lihavainen, H., Lunder, C., Luoma, K., Lyamani, H., Marinoni, A., Mihalopoulos, N., Moerman, M., Nicolas, J., O'Dowd, C., Petäjä, T., Petit, J.E., Pichon, J. M., Prokopciuk, N., Putaud, J.P., Rodríguez, S., Sciare, J., Sellegri, K., Swietlicki, E., Titos, G., Tuch, T., Tunved, P., Ulevicius, V., Vaishya, A., Vana, M., Virkkula, A., Vratolis, S., Weingartner, E., Wiedensohler, A. and Laj, P. (2018). A European aerosol phenomenology - 6: Scattering properties of atmospheric aerosol particles from 28 
ACTRIS sites. Atmos. Chem. Phys. 18: 877-7911, doi: 10.5194/acp-18-7877-2018.

Raatikainen, T., Hyvärinen, A.P., Hatakka, J., Panwar, T.S., Hooda, R.K., Sharma, V.P. and Lihavainen, H. (2014). The effect of boundary layer dynamics on aerosol properties at the Indo-Gangetic plains and at the foothills of the Himalayas. Atmos. Environ. 89: 548555, doi: 10.1016/j.atmosenv.2014.02.058.

Reddington, C.L., Carslaw, K.S., Stier, P., Schutgens, N., Coe, H., Liu, D., Allan, J. Browse, J., Pringle, K.J., Lee, L.A., Yoshioka, M., Johnson, J.S., Regayre, L.A., Spracklen, D.V., Mann, G.W., Clarke, A., Hermann, M., Henning, S., Wex, H., Kristensen, T.B., Leaitch, W.R., Pöschl, U., Rose, D., Andreae, M.O., Schmale, J., Kondo, Y., Oshima, N., Schwarz, J.P., Nenes, A., Anderson, B., Roberts, J.G., Snider, C.R., Leck, C., Quinn, P.K., Chi, X., Ding, A., Jimenez, J.L. and Zhang, Q. (2017). The global aerosol synthesis and science project (GASSP): Measurements and modeling to reduce uncertainty. Bull. Am. Meteorol. Soc. 98: 18571877, doi: 10.1175/BAMS-D-15-00317.1.

Sanroma, E., Palle, E. and Sanchez-Lorenzo, A. (2010). Long-term changes in insolation and temperatures at different altitudes. Environ. Res. Lett. 5: 024006, doi: 10.1088/1748-9326/5/2/024006.

Schmeisser, L., Andrews, E., Ogren, J.A., Sheridan, P., Jefferson, A., Sharma, S., Kim, J.E., Sherman, J.P., Sorribas, M., Kalapov, I., Arsov, T., Angelov, C., MayolBracero, O.L., Labuschagne, C., Kim, S.W., Hoffer, A., Lin, N.H., Chia, H.P., Bergin, M., Sun, J., Liu, P. and $\mathrm{Wu}, \mathrm{H}$. (2017). Classifying aerosol type using in situ surface spectral aerosol optical properties. Atmos. Chem. Phys. 17: 12097-12120.

Spracklen, D.V., Mickley, L.J., Logan, J.A., Hudman, R.C., Yevich, R., Flannigan, M.D. and Westerling, A.L. (2009). Impacts of climate change from 2000 to 2050 on wildfire activity and carbonaceous aerosol concentrations in the western United States. J. Geophys. Res. 114: 2156-2202, doi: 10.1029/2008JD010966.

Stocker, T.F., Qin, D., Plattner, G.K., Alexander, L.V., Allen, S.K., Bindoff, N.L., Bréon, F.M., Church, J.A., Cubasch, U., Emori, S., Forster, P., Friedlingstein, P., Gillett, N., Gregory, J.M., Hartmann, D.L., Jansen, E., Kirtman, B., Knutti, R., Krishna Kumar, K., Lemke, P., Marotzke, J., Masson-Delmotte, V., Meehl, G.A., Mokhov, I.I., Piao, S., Ramaswamy, V., Randall, D., Rhein, M., Rojas, M., Sabine, C., Shindell, D., Talley, L.D., Vaughan,
D.G. and Xie, S.P. (2013). Technical summary. In: Climate Change 2013: The Physical Science Basis. Contribution of Working Group I to the Fifth Assessment Report of the Intergovernmental Panel on Climate Change, Stocker, T.F., Qin, D., Plattner, G.K., Tignor, M., Allen, S.K., Boschung, J., Nauels, A., Xia, Y., Bex, V. and Midgley, P.M. (Eds.), Cambridge University Press, Cambridge, United Kingdom and New York, NY, USA.

Twomey, S. (1977). The influence of pollution on the shortwave albedo of clouds. J. Atmos. Sci. 34: 11491152, doi: 10.1175/1520-0469(1977)034<1149:TIOPOT $>2.0 . \mathrm{CO} ; 2$.

Wang, Z., French, J., Vali, G., Wechsler, P., Haimov, S., Rodi, A., Deng, M., Leon, D., Snider, J., Peng, L. and Pazmany, A.L. (2012). Single Aircraft Integration of Remote Sensing and In Situ Sampling for the Study of Cloud Microphysics and Dynamics. Bull. Am. Meteorol. Soc. 93: 653-668, doi: 10.1175/BAMS-D-11-00044.1.

Westerling, A.L., Hidalgo, H.G., Cayan, D.R. and Swetnam, T.W. (2006). Warming and earlier spring increase western US forest wildfire activity. Science 313: 940943.

Yu, H., Remer, L.A., Chin, M., Bian, H., Kleidman, R.G., and Diehl, T. (2008). A satellite-based assessment of transpacific transport of pollution aerosol. J. Geophys. Res. 113: D14S12, doi: 10.1029/2007JD009349.

Yu, H., Quinn, P.K., Feingold, G., Remer, L.A., Kahn, R.A., Chin, M., and Schwartz, S.E. (2009). Remote sensing and in situ measurements of aerosol properties, burdens, and radiative forcing in atmospheric aerosol properties and climate impacts. A report by the US climate change science program and the subcommittee on global change research, Chin, M., Kahn, R.A. and Schwartz, S.E. (Eds.), National Aeronautics and Space Administration, Washington, D.C., US.

Zhao, Y., Hallar, A.G. and Mazzoleni, L.R. (2013). Atmospheric organic matter in clouds: Exact masses and molecular formula identification using ultrahighresolution FT-ICR mass spectrometry. Atmos. Chem. Phys. 13: 12343-12362, doi: 10.5194/acp-13-12343-2013.

Received for review, May 31, 2018 Revised, March 13, 2019 Accepted, April 18, 2019 